\title{
THE NEW RELATION OF THE FEDERAL GOVERNMENT TO STATE AND LOCAL COMMUNITIES
}

\author{
HOWARD LEE MCBAIN \\ New York City ${ }^{1}$
}

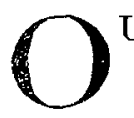

UR constitutional system was on the whole erected to withstand not to assimilate economic revolutions. It is nevertheless a fact that, in spite of the revilers against its obstructive staticism, the chief marvel of our constitution has been its capacity for absorbing unforseen changes, however gradually. The literal "a b c's" of our political institutions considered in the light of their adaptability to politico-economic changes are: (a) our federal system with its division of powers between the national government and the forty-eight states of the Union; (b) our written constitutions imposing definite and indefinite prohibitions on our governments, state and national; and (c) the power of our courts to enforce these prohibitions by judicial veto that varies in the quality of its finality. This is merely to recite elements in our political system that are within the range of school-boy erudition. But in the face of vaguely forecasted changes in our national economy these commonplaces of our institutions assume fresh significances. A new glance at our old institutions cannot be harmful; at the worst it can only be useless.

\section{CONSTITUTIONAL LIMITATIONS}

Under our existing constitutional arrangement it is perfectly obvious that congress is limited in its legal competence to put into effect the whole of any widespread program of economic readjustment. The apparently unrestricted war powers of congress cannot be taken as a measure of national powers in time of peace. Out of the vast extension of national activity for war purposes it is highly probable that a considerable amount of the new centralized control will remain during the immediate postwar period, and that some of it will survive as permanent. Conceding this, everybody yet knows that congress can act only within a preseribed, though somewhat uncertainly prescribed, orbit. The first question that obviously presents itself is: What may congress do by direction? This question goes manifestly to the concrete issues of readjustment and involves consideration of many intricacies of our constitutional law. I cannot therefore attempt to answer it in detail. A few points only can be noted.

DEMOBILIZATION, MILITARY AND INDUSTRIAL

I take it as foregone that congress is competent under its war powers to provide in every way that is necessary for the demobilization of the

\footnotetext{
1 Eaton Professor of Munieipal Science and Administration, Columbia University.
} 
military forces of the United States, including adequate provision for the prevention of economic distress by reason of unemployment, the care of the sick and wounded, and the re-education of the maimed and crippled. In this no inconsiderable undertaking many questions of policy are involved. At least one step has already been taken by congress in the enactment of the Smith-Sears bill for the vocational re-education of the permanently injured. In whatever further steps are taken it is probable that congress will act for the most part by direction and not through the medium of state and local agencies. The questions involved are, however, questions of policy and not of power. Surely, if congress can create and maintain armies and navies, congress can also provide in any way that it sees fit for a sane and decent demobilization of the forces thathave been called into being.

The transformation of industries from a war to a peace footing involves a far more difficult question of congressional competence. This is a serious problem even though temporary in character. Moreover, some of the policies that might be adopted in reference to it would present serious constitutional questions and might involve policies that would grow into permanency. For instance, do the war powers of congress include the power to provide during the transitional period financial assistance to those numerous industrial plants that have been lured into war work either by the hope of profits or by patriotism or by both? Perhaps the closest answer that we have to this question is the fact that more than half a century ago it was thought no less proper than legal that our governments, national, state, and local, should give financial aid to the exploitation and development of railways.

\section{THE WAR FINANCE CORPORATION}

We have also with us as a present war measure the War Finance Corporation, endowed with power to lend support from the national treasury to necessary industrial and utility enterprises. Disastrous were the consequences of public aid for railways during the era when that policy had unbridled and haphazard vogue throughout the country. It received, nevertheless, the stamp of judicial approval. The constitutionality of the War Finance Corporation has not been brought to test before the courts.

There are few who would not agree perhaps that the proposal that the government should lend financial assistance to aid war industries in their temporary struggle for peace readjustment has as much foundation in reason and should have as much foundation in law as the policy of government aid to railways, if not of government aid to industries and utilities in time of war. More especially would this be true if such aid were extended under strict supervision and control (elements that were practically unknown in the era of railway aid) not only to the end that loans 
should be honestly and efficiently utilized but also to the end that industries should be promoted with reference to the needs of employment and to the immediate economic needs of our own country as well as of the countries with which we have been associated in the recent great enterprise.

\section{A PEACE FINANCE CORPORATION}

The time has passed when war can be regarded as an undertaking isolated from industry. Congress cannot raise and support an army and a navy for modern warfare unless congress also raises and supports war industries, either by direct government action or by inducement. Our war industries, although in the main under private control, are an integral part of our armed forces. Whatever their motive, it is a fact that many industries have turned to war production and thereby have become an indistinguishable part of our gigantic machinery of war. Considering the national welfare the demobilization of these industries is a duty that differs only in important degree from the duty of demobilizing the armed forces. I do not see how the courts could successfully maintain that the relocation of war industries has no relation whatever to the raising and support of an army and navy. I am well aware of the doctrine of no taxation for a private purpose and of the cases in which this doctrine has been applied by the courts to defeat projects for government aid to private industry. So far as I know, however, the doctrine has never been wielded against an act of congress. And I am inclined to believe that a Peace Finance Corporation, of a temporary character, would be sustained by the courts as a proper exercise of the war powers of congress.

\section{THE QUESTION OF POWER}

I am not here advocating government aid to war industries in the transition period that is upon us. I am speaking only to the question of power. Moreover, in referring to the matter at all, I have far less in mind the interests of capitalist war producers than the interests of the laborers whom they employ.. Until our entire economic order is fundamentally altered the opportunity for labor must depend upon the directions of capital, wise or capricious. By and large, capitalists can far more easily survive this period of transition than can their employes. Direct national aid to these employes may seem to be more consonant with the spirit of the hour than direct aid to their capitalist employers. It is nevertheless obvious that direct aid to these employes (insuring them, for example, against unemployment during the era of transition), would involve an elaborate administrative machinery. It would not serve to direct the courses of industrial rehabilitation, and it is possible that it would obstruct rather than facilitate a return to normal conditions in industry. Needless to say that through the medium of government aid to industries the status of labor in the assisted plants could be and should 
be dictated by the government itself just as it has been largely dictated during the war period. So far, however, as the question of congressional competence is concerned, direct aid to employes in these circumstances would doubtless present the same question of constitutional law as direct aid to industries.

In any policy that congress may pursue in respect to this matter it is improbable that the states or local governments will be called upon for much, if any, collaboration. These governments have little machinery that could be adapted to the purpose of effectuating such a policy. If direct aid should be extended to labor, of course the recently created federal employment service would be expanded and utilized, and it is possible that state and local services might also find opportunities for usefulness in this connection. Needless to say I am not at this point referring to the whole great question of the future policy of our governments toward the subject of unemployment.

It may easily happen that, in view of the manifest economic supremacy of this country and of the appalling world demand for the materials of rehabilitation, our industries will readjust themselves with such marvelous rapidity that there will be little need for government assistance either to capital or to labor. ${ }^{1}$

\section{NATIONAL REGULATION DURING THE TRANSITION PERIOD}

The powers of the national government to fix the prices of certain basic commodities and to regulate consumption and distribution have not been judicially questioned as war powers. Whether these policies can be legally continued in time of peace, even during the era of demobilization is open to grave doubt. They probably could not be sustained upon the ground I have advanced in possible support of action by congress in connection with military and industrial demobilization. The fixing of prices and the control of consumption and distribution have certainly borne direct relation to the raising and support of military forces and to the actual conduct of war; but they certainly bear a very much less direct relation to demobilization as such, or indeed to any power that the national government has been regarded as possessing in time of peace. It is barely possible that the power of congress to regulate commerce might be invoked in support of price fixing. Under this power congress has regulated the rates of interstate carriers and in effect the wages of some of their employes even before government operation was put into effect as a war measure. Congress has also established standards for certain commodities that may be shipped in such commerce. From these policies, sanctioned by the courts, the regulation of the prices of interstate commerce commodities may seem a very small step; but it is certainly one that would be vigorously fought both as policy and as law. It is simply a

\footnotetext{
${ }^{1}$ Many evidences of this probability have developed since this was written.

H. L. M.
} 
fact that, however broadly the courts have asserted the power of our governments, state and national, to regulate the prices of businesses "affected with a public interest," such regulation has in practice been confined almost exclusively to the distinguishable class of business popularly known as public utilities. Whether the courts are ready to sustain a new and very much broader application of an old broadly asserted principle remains to be seen if the policy is attempted.

If congress has the power to regulate the prices of interstate commerce commodities, it may perhaps be regarded as settled that the states have the power to regulate the prices of commodities that enter into intrastate commerce. Moreover, it is probable that the exercise of such power by congress would lead to some exercise of a similar power by the states. Price-fixing is, at best a politico-economic policy of highly questionable wisdom. Whatever theoretical arguments may be advanced in its favor, it is a policy that involves enormous practical difficulties. It can be justified only in time of great emergency. Our experience even in the realm of utility rate control has surely not been sufficiently happy to warrant, as a permanent policy, a wide extension of price control by government order. It may be, however, that a temporary continuation of this policy will be desirable if legal competence for $i t ̦$ exercise can be found.

A recent utterance of Chairman Baruch of the War Industries Board, seems to indicate that the control of that great organization will continue "for some time to come." He is quoted as saying that raw materials made available by the reduction of war requirements and the cancellation of war contracts "will be released and allocated by the War Industries Board for use in supplying civilian and export demands." There is to be also only a "gradual lifting of the restrictions and curtailments that have been imposed upon industry by the exigency of the war."1 It may be that such a policy will meet with general acquiescence by industry. But it must not be forgotten that the single minded purpose of the nation has been accomplished. Patriotism is no longer called to its highest form of expression. Industry will be restless, even rebellious, under government restraint. It may well result that the constitutional competence of the national government to "allocate" raw materials in time of peace and to lift restrictions only "gradually" will be drawn into question. Of course it is possible that the government may exercise a degree of control in this direction so long as government operation of transportation continues, although the rule of law is fairly established that even governments must in the operation of utilities furnish equal service to all who apply.

In all of this great problem, however,-important as it is-there is little, if any, question touching the subject immediately before us, the relation of the national government to state and local governments. The

${ }^{1}$ Since this was written there are many evidences that the control exercised by the War Industries Boards is rapidly disintegrating. H. L. M. 
problem is wholly national, whether viewed in its constitutional, its legislative, or its administrative aspects.

Let us turn now to consider a few questions relating to possible public policies of a more permanent character.

\section{GOVERNMENT OWNERSHIP}

It is not my purpose to discuss the question of the policy of national ownership of the railways, the telephones, the telegraphs and allied utilities. This question will doubtless be fiercely fought in the immediate days ahead. In my opinion it is certain that congress is legally competent to acquire these utilities under the power to regulate interstate commerce and the power to establish post-offices and post-roads. Whether in the face of our stupendous national debt congress can see its way clear to raise the money for their acquisition and whether these utilities ought to pass over to government ownership as a matter of policy are wholly different questions. It seems fairly certain that these great arteries of the nation's economic and social life will never be handed back to private management under the system of public supervision that prevailed so short a time back. A discussion, however, of the economic, political, and legal questions involved in the future policy of the government toward these utilities is not germane to my subject. Whatever that policy may be it is manifest that the state and local governments will have little if anything to do with the matter. Under government ownership our state utility commissions will cease to function with reference to the utilities that are taken over. Even under a scheme of private ownership with government operation, or with joint government and private operation, the powers of these state agencies cannot fail to be greatly curtailed.

In respect to any proposal that may be advanced for the national ownership of the sources of industry, such as mines or waterpower sites, there would also be no question of state or local participation. Here again the competence of congress can scarcely be questioned, at least if the acquisition of forest lands by purchase may be taken as a precedent that establishes a rule of competency. Whether congress could acquire such properties by condemnation, as it probably could in the case of the railways and the other utilities mentioned, is open to some doubt. To the extent that natural resources or even industrial enterprises require development in order to insure the self-sufficiency or complete economic independence of the country, it is probable that the power of the national government is without limit. In the light of the lessons of the war, action in this regard could readily be sustained under the war powers of congress.

THE GOVERNMENT'S REGULATION OF CAPITAL AND LABOR

It seems almost inevitable that the so-called trust problem will be once more to the fore. Nobody is satisfied with the economic results of the Sherman Act, and the Federal Trade Commission has assuredly had 
no conspicuous measure of success-nothing comparable, for example, to that of the Federal Reserve Board in another field of control. It seems possible at least that our entire policy in respect to concentration in industry may be completely reversed; it will certainly be reconsidered. What is apparently needed is not so much government war upon concentration as such, but government war upon the evils of industry whether they obtain in concentration or in competition. It is impossible to forecast how this great problem will be met. It is certainly a national problem and not one that ean or ought to be shared with the states. It is not a problem of big business only, and it is to be regretted that the sole existing constitutional avenue for congressional approach is the commerce power, which has well-known limitations in this respect.

With the discontinuance of war contracts and with the absence of opportunity to appeal to patriotism or to threaten direct government operation, the chief modes by which the federal government has maintained harmonious relations between capital and labor will disappear. What, if anything, is to be substituted? Compulsory arbitration is open to serious objections in point of policy, not to mention the grave doubt that exists as to the constitutional competence of congress to enact such a policy into law, even though the law applied only to interstate carriers and to those enterprises that ship products in interstate and foreign commerce. Harmony between labor and capital centers chiefly around questions of wages, hours of labor, and related matters. But neither labor nor capital is unqualifiedly enthusiastic about having these matters settled by law or by administrative action founded upon law.

There is one kind of legislation, however, that organized labor would unreservedly endorse and that capital would for the most part oppose. I refer to legislation that looks to legal recognition of and protection for the principle of collective bargaining. That statutory support for labor unions would strengthen the principle of collective bargain is unquestionable. Whether it would or would not result in greater harmony between capital and labor is perhaps open to some debate. In 1898 Congress evidently thought that it would so result, at least in the case of interstate carriers. But in 1908 the supreme court, being probably unconvinced, declared the congressional act to this end void. In the opinion of the court the act was not within the power of congress to regulate cornmerce, and even if it were, it deprived the carrier and the employe of that vague thing known as freedom of contract which is guaranteed by the requirement of due process of law. So, also, a state statute directed to a similar end was invalidated by the supreme court in 1915 because it interfered with this same freedom. And more recently still it has been declared that even in the absence of statute, labor union officials may be enjoined from attempting to interfere with the status quo arrangeinents of a closed non-union enterprise. 
Although there were strong minority dissents in each of these cases, it is perfectly obvious that the majority of the court that shapes the course of the law is to date opposed to the proposition that any of our units of government should lend the aid of the law to the principle of collective bargaining. So long as this judicial attitude maintains its front, it is idle to argue that either congress or the state legislatures may lend statutory assistance to labor unions except through the narrow door of government contracts. Certainly congress cannot apply generally to the industries of interstate commerce a regulation that it could not impose upon the direct carriers of such commerce. How long this judicial front can or will be held is wholly another question. For the moment, at any rate, such harmony between labor and capital as can be created by legally strengthening the position of the union is interdicted. Neither congress nor the states can act.

THE CHILD LABOR DECISION

The recent veto of the federal child labor law by the supreme court arrests, for the time being at least, the movement for federal control over the standards and conditions of labor in the country: The court had previously permitted congress to advance from regulating the carriers of commerce to regulating the articles that enter into commerce; but the bars have been raised against any further advance. Congress may not regulate the kind of labor that may be employed in the manufacture of such articles, and presumably therefore congress may not regulate the conditions under which such labor may be employed--maximum hours, for example, or minimum wages - or the conditions of the establishments in which they work-sanitary or safety conditions, for instance. Here, then, is an increasingly important field that is still left exclusively to the control of the states. That the child labor law was defeated because of its potential implication as to future legislation by congress rather than because of its immediate specifications is beyond question. Indeed this was very nearly avowed with frankness by the supreme court. That the decision is the last word of the court upon this subject is extremely doubtful. But for the moment it stands.

I point to these restrictions upon the powers of both national and state governments in the matter of regulating labor and capital, not with a view to emphasizing a legalistic view of the situation. The law and the power of the courts are under our system of jurisprudence facts that must be reckoned with. When I hear talk about the democratization of industry by congressional action requiring labor participation in the management of plants; or the stabilization of industry by national control of raw materials, national taxation upon plants for idle days, and a national requirement that laborers shall be employed upon a yearly contractual basis; or the establishment of industrial peace by compulsory arbitration, compulsory recognition of unions, compulsory minimum wage scales, and 
compulsory maximum hours of work-when I hear talk of this kind, I cannot but wonder whether those who advance these proposals have any notion whatever of the legal difficulties that stand to be overcome.

Manifestly war conditions have taught both labor and capital many lessons of vital importance. It is not unlikely that their capacity for co-operation has been developed. It is also not unlikely that capital will accept certain innovations in the position of labor, in part because it has found them both useful and workable, in part because of their essential justice. Especially in this possible in the probable era of prosperity that is before us. But this is wholly a different thing from government action.

\section{GOVERNMENT AID}

I have already spoken of the possibility of national aid to industries or employes during the demobilization period. But the question of national aid presents larger aspects than this. Broadly speaking, there is nothing new about the principle of national aid, whether to individuals or to state and local governments and whether in reference to a subject matter over which congress has control or otherwise. Many promotional services in the departments of agriculture and of commerce have been established to aid private persons in their economic pursuits, although not by means of direct payments. We are familiar also with direct national aid to institutions for agricultural and military education, and with ship subsidies. More recently aid has been provided for the promotion of vocational education, for the building of roads, and for farmers, aid to the latter, however, being only in the form of loans. Congress has no express power to regulate or control agriculture, or education, or roadbuilding (except post-roads).

Large possibilities inhere in this method of bringing national pressure to bear upon certain economic problems as well as upon state and local activities. I can mention only one or two aspects of the matter.

The problem of compensation for industrial injuries is now fairly cared for by most of the states, and it is probable that the machinery of this service will be steadily improved. The principle has been accepted that the cost of industrial accidents is a cost properly known by industry itself. It is not so clear, however, that sickness, old age, and unemployment are proper burdens of industry as such. Are they not rather burdens which society as a whole should assume?. And is it not appropriate that these burdens should be assumed by the national government rather than by our local units of government? We have no precedent for congressional action in such matters except the unrelated precedent of military pensions and the stupendous war risk insurance recently established. Congress certainly has no express power in the premises. But there is the general precedent of national aid to enterprises that are beyond the reguJatory power of congress, and there is the fact already mentioned that 
no act of congress has ever been declared void on the ground that it imposed taxes for a private purpose. Proposals for the establishment of such schemes of insurance would be fought not only on legal grounds but also with the age-worn slogan of paternalism. Yet sooner or later, they are bound to come.

Especially would insurance against unemployment, if carefully administered, be an equalizing and stabilizing force in society. In connection with this it is manifest that employment upon public works in times of economic depression is a possibility not to be ignored. Now in the matter of public works our cities are our largest spending units. Congress has no control over them. But through the medium of financial aid to these governmental units during periods of depression congress could exert a large influence upon their activities.

Again, in the matter of education, particularly in its relation to the immigrant, it is high time that the national government should exert a larger measure of influence. I am aware of the fact that the policy of subsidizing local communities or institutions for educational purposes, whether employed by the national or the state governments, has not furnished a very satisfactory means of compelling compliance with standards and conditions. But there is no inherent reason why such a policy can not be made effective. It certainly offers at the moment the only possible method by which the influence of the nation as a whole can be brought to bear upon our widely variant and in many parts of the country wholly insufficient systems of education.

\section{OUR FEDERAL SYSTEM RECONSIDERED}

You are perhaps wondering-and not without reason-when I shall arrive at my subject, the new relation of the federal government to state and local communities. I have already arrived. I do not believe that there is going to be much that is strikingly new in this relation except in the matter of co-operative spirit; and even in respect to this latter we must not ignore the large amount of co-operation that has prevailed in the past between administrative agencies of the national government and corresponding agencies in the state and local governments.

In time of war when centralization of authority and immediateness of action are of the essence, the disadvantages of a federal system of government are obvious. But war is an abnormal circumstance. I hold no brief for federalism as a principle and still less do I hold brief for the rights of the states, either legal or moral. There is much that is arbitrary in our federal system and much that is annoying. The division of powers between the nation and the states is by no means ideal. But I am not ready to see our federal arrangement sent to the institutional scrap heap; and in this, I believe, I am one of a vast majority of the American people. For, wholly apart from the threadbare shibboleth of state against national 
rights, every thoughtful person must recognize that in a country as large and diversified as ours, a division of powers which leaves to the states an important sphere of autonomy has certain obvious advantages in normal times of gradual economic and political change. Perhaps the chief of these advantages is the opportunity which it offers for experimentation under the urge of a localized public opinion that does not have to wait upon the conversion of the entire nation to its hopes or its beliefs. Our states are notorious copyists. Politico-economic experiments, proved and unproved, improved and unimproved, spread rapidly from state to state. Thus do acorns of real or phantasmal reform, planted in a single state, grow into sturdy, if often asymmetrical, national oaks. I look for steady expansion of national powers; but I should regret to see this expansion accomplished by constitutional amendments transferring to exclusive national control a large number of the powers now exercised by the states.

NATIONAL-STATE RELATIONS

In this connection I should like to call your attention to a situation in respect to our national-state relations that is often misunderstood. In reference to legislation such as the federal child labor law we hear much talk about the national government's "invasion" of the sphere of state control, and the general impression created is that congressional action supersedes and wholly displaces state action upon the subject matter involved. Nothing is further from the facts. The positive regulations of the states remain untouched.

Suppose, for example, that the federal child labor law had been upheld. It provided fourteen years as the minimum age; and establishments engaged in the production of interstate commerce commodities could not employ a child under that age. Now suppose that the law of a particular state fixed twelve years as the minimum. Such a state law does not positively authorize the employment of children above the minimum set; it merely prohibits the employment of children under that minimum. It would be enforced as to all plants not engaged in manufacturing commodities covered by the federal law. It would simply be unnecessary to enforce it in plants that were so engaged because of the superior requirements of the national law.

Suppose, on the other hand, that the law of a particular state established a sixteen-year minimum. The federal statute would not enter such a state and authorize a lower requirement. In fact, if adequate enforcement of the state law be conceded, the federal law would be useless in such a state; for every plant that complied with the state law would of necessity more than comply with the federal law.

\section{INVASION OF STATE CONTROL}

It is manifest, therefore, that national regulations in such a field as this are in supplement of, not in substitute for, state regulations. They 
"invade" the sphere of state control only in the sense that they may prohibit in part what the state by inaction permits. They can not and do not permit what the state by positive action prohibits. Moreover, it is simply a fact that federal action, far from negativing or interfering with action by the states, is often a stimulus to increased state activity. There is no question, for instance, that both states and cities are far more active to-day in the matter of protecting the purity of food supplies than they were prior to the federal pure food legislation of 1906 . They do not often duplicate the federal government's work; but they supplement it and co-operate. Under the impulse of federal example, they are spending more and acting more, even in what is for practical, though not for legal reasons, a more circumscribed field of operations. If it be true that no state or city can prohibit the sale of comestibles that the federal government does not shut out from interstate and foreign commerce (under the doctrine that the right to import carries with it the right to sell), it is also true that the state or city was powerless to prohibit such sale prior to the federal legislation. The national government did not, therefore, trench upon the powers of the states in this matter; rather did it occupy a field which the states did not and, under the ban of the courts, could not occupy.

In studying the relation of our national government to our state and local governments it is of tremendous importance that this situation be clearly conceived. What I have said is not true of every power that congress may attempt to exercise. When state bank notes were taxed out of existence, congress directly interfered with and in effect prohibited what the states positively permitted. And when the federal bankruptcy law became effective the state laws upon the subject were in effect, though not in form, repealed. But when congress acts under what has become its most expansile power for effectuating economic and social legislation-to wit, the commerce power-the effect is as I have indicated. We may rail at the limitations of this power; we may be sometimes discouraged at the brittle quality of its alleged expansile attribute when the firm hands of the courts take hold of it; but unless we are ready to scrap our federal system completely, we must recognize that the gradual and halting expansion of national activity under the commerce clause, receiving stimulus from, and giving stimulus to, state action of similar character, may in the long run be more satisfactory than a process by which one after another of the powers of the states should be exclusively taken over by the national government.

THE PROPOSAL FOR FEDERALIZATION

It is a curious fact that at the very moment when there is in this country some expectation that the powers of the states in our federal system will be greatly weakened as a result of war and after-war conditions, the pro- 
posal for federalization is being earnestly put forward in Great Britain, more forcefully than ever before-federalization, that is, not of the British Empire but of Great Britain and Ireland. It is true that this movement is prompted largely by the perennial Irish question; but it is receiving strong support also in point of principle and in point of political wisdom, upon the theory that a sphere of autonomy for England, Scotland, Ireland and Wales would relieve Parliament of some of its burdens and would foster a healthy spirit of self-dependence on the part of the several autonomous units. The world is at unrest. Let us not be enamored of change merely because we feel this restlessness.

\title{
NATION PLANNING
}

\author{
FREDERICK L. ACKERMAN \\ New York $^{1}$
}

THE NATIONAL PURPOSE

$I^{N}$

$\mathrm{N}$ this tremendous world war the areas of united action have expanded; the common good,--the aims of all free men have become vivid. And to nations, states, municipalities, to property, capital, credit, to groups, individuals and to the labor of brain and hand new values have been assigned which express our new concept of their relative worth as factors contributing to the purpose made vivid in this war.

And this purpose is the achievement of a state of true democracy, international and national, which assigns to the individual the highest value and yet demands that for the good of all he victoriously subordinate himself.

But can a national purpose in times of war differ from a true democratic national purpose in times of peace? Can the worth of the individual vary with the degree of vividness with which the aims of a true democracy are revealed?

The national purpose in times of peace and the national purpose in times of war must coincide; and the value of the individual cannot change simply because his worth is made more vivid by the call to arms. As the truly national purpose is revealed it is the value of nations, of states, of property, of capital and credit which really shifts as we see more clearly their true worth as factors contributing toward a true democracy.

And so, it is obvious, when we glance back to the pre-war days, that our function for the time being is not primarily that of developing a new technique of administration or government; it is that of making perfectly clear to the masses of men what is really meant by the term democracy. Our task is to present a truly rational philosophy of life in such simple terms and through the use of such simple illustrations as would demon-

${ }^{1}$ Emergency Fleet Corporation. 